\title{
An Analysis of the Relationship between Students' Metacognitive Awareness and Students' Cognitive Learning Outcomes in Pre-service Teachers
}

\author{
Wisnu Juli Wiono ${ }^{1}$, Nadya Meriza ${ }^{2}$, Tia Agnesa ${ }^{3}$ \\ \{wisnujuliwiono@gmail.com¹ ${ }^{1}$, nadya.meriza@fkip.unila.ac.id ${ }^{2}$, tia.agnesa88@fkip.unila.ac.id ${ }^{3}$ \} \\ Biology Education Department University of Lampung, Lampung Indonesia ${ }^{1}$, \\ Biology Education Department University of Lampung, Lampung Indonesia ${ }^{2}$, \\ Mathematic Education Department University of Lampung, Lampung Indonesia ${ }^{3}$
}

\begin{abstract}
The purpose of this study was to determine the profile of the relationship between the level of metacognitive awareness and cognitive learning outcomes of student biology teacher candidates at Lampung University. This study used a survey research design with a sample size of students. Metacognitive awareness questionnaires and cognitive question sheets were provided in this study. The questionnaire measures eight aspects of metacognitive awareness, namely declarative knowledge, procedural knowledge, conditional knowledge, planning, information management strategies, comprehension monitoring, debugging strategies, and evaluation. Question sheets evaluate cognitive learning outcomes. The results showed that the students had a very good level of metacognitive awareness (54\%). There was no significant relationship between metacognitive awareness and student cognitive learning outcomes $(r=0.898)$. It was concluded that metacognitive awareness did not affect cognitive learning outcomes at levels $\mathrm{C} 1, \mathrm{C} 2$ and $\mathrm{C} 3$.
\end{abstract}

Keywords: Metacognitive awareness, Cognitive learning outcomes, pree-service teacher

\section{Introduction}

Lecture activities that are specifically designed to develop learning outcomes of students' metacognitive dimensions are not very common. Most educators focus more on the learning outcomes of cognitive dimensions and less psychomotor. Although it was found that some educators designed lectures by involving metacognitive dimensions, their development was not comprehensively measured. Still cognitive learning outcomes are the main consideration in describing the characteristics of students in a course. Lecture activities that involve metacognition activities will get more meaningful learning outcomes. This is because the metacognition dimension is one component in building problem-solving abilities in students in addition to experience, supervision, beliefs and habits in the community [1]. Metacognition also plays a role in recognizing obstacles when solving problems through knowledge and the processes used to direct successful thought processes [2]. Through metacognition, a person will be able to become an independent learner, foster an honest attitude, dare to admit mistakes, and improve learning outcomes significantly [3]. There are three important stages during the metacognitive control process: planning, monitoring and evaluation [4].

Developing metacognition in a person requires strategies in the form of routines that represent specific mental actions and are part of a complex process carried out in order to achieve goals such as understanding what has been read [5]. Someone who has learning difficulties can be caused by not having a metacognition strategy. The form can be in the form of difficulties in mapping problems that have an 
impact on the difficulty of understanding a lesson comprehensively [6]. Metacognition strategies refer to ways to increase awareness of the processes of thinking and learning that apply so that when this awareness is realized, metacognitive skills will emerge where a person can escort his mind by designing, monitoring and assessing what he is learning [7].

Someone with a good awareness of metacognition will lead to self-regulation by planning, to directing and evaluating. The level of metacognition awareness can be helped towards self-awareness if supported by the learning environment [8]. Among ways to practice metacognition awareness is to get used to using effective learning strategies and to explore awareness for learning [8]. The more someone knows about the process of thinking and learning, the greater the awareness of metacognitive. Furthermore, this will have an impact on the learning process and achievements of students [9]. The results of research by Nuryana \& Sugiarto [10], Coutinho [11], and Ulfah et al. [8], show that there is a significant relationship between metacognition awareness and student learning outcomes. In addition to metacognition awareness, achievement levels are also influenced by intellectual abilities [12].

Based on the results of analytical theoretical and practical studies about the goodness of metacognition awareness in directing one's achievement, then efforts to see the profile of metacognition awareness are feasible to run. The research results can be used as a basis for other development research in the same field or are still in contact.

\section{Method}

This research uses descriptive method, which is an attempt to describe the subject/object of research based on facts obtained in the present as it is [13]. This method was chosen because it is aligned with research objectives that will uncover and analyze the level of metacognition awareness of students who take the Animal Behavior Course. This study took 32 students as subjects who were taking Animal Behavior courses. The research data was collected by giving a MAI (Metacognition Awareness Inventory) questionnaire and a concept understanding question sheet. MAI questionnaire refers to the results of the development of Schraw, G. \& Dennison, R.S [13]. Interpretation of metacognition awareness levels uses the Green (2002) reference, with details as outlined in Table 1 . The question sheets are used to measure cognitive learning outcomes and are validated by assessment expert lecturers. The collected data was tested for normality (Kolmogorov-Smirnov) with the help of SPSS.16. Furthermore, data on the measurement of metacognition awareness and learning outcomes were analyzed using SPSS.16 to determine the level of significance of the effect. More clearly, the flow of research is illustrated as Figure 1.

The MAI instrument developed by Schraw, G. \& Dennison, R.S. (1994) generally measure two aspects of metacognition, namely knowledge about cognition and cognitive regulation. The knowledge aspect of cognition encompasses the level of student knowledge, especially declarative knowledge, procedural knowledge and conditional knowledge. While aspects of the regulation of cognition focus in measuring the level of planning, information management strategies (IMS), overall monitoring, tracking strategies, and evaluations.

Table 1. Estimates of Metacognition Awareness Levels

\begin{tabular}{|c|c|c|c|}
\hline $\begin{array}{c}\text { Score } \\
\text { interval }\end{array}$ & Level & Term & Description \\
\hline $0-18$ & 0 & Not yet & Not yet lead to cognition. \\
\hline $19-36$ & 1 & Risk & $\begin{array}{l}\text { Does not appear to have an awareness of thinking as a } \\
\text { process. }\end{array}$ \\
\hline
\end{tabular}




\begin{tabular}{|c|c|c|c|}
\hline $37-54$ & 2 & $\begin{array}{l}\text { Not very } \\
\text { good }\end{array}$ & $\begin{array}{l}\text { Not being able to separate what is thought from how he } \\
\text { thinks. }\end{array}$ \\
\hline $55-72$ & 3 & Grow & Can be assisted towards self-awareness if moved or supported. \\
\hline $73-90$ & 4 & Good & $\begin{array}{l}\text { Conscious of his own thinking and can distinguish the stages } \\
\text { of self-elaboration input and the output of his own mind. }\end{array}$ \\
\hline $91-100$ & 5 & Very good & $\begin{array}{l}\text { Able to use metacognition skills regularly to manage their } \\
\text { own thinking and learning processes. Aware of the many } \\
\text { possibilities of thinking, being able to use them smoothly and } \\
\text { reflecting on the thought process. }\end{array}$ \\
\hline
\end{tabular}

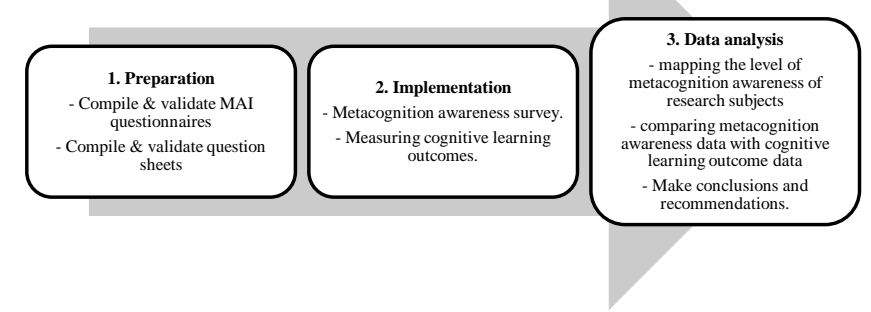

Fig. 1. Research Flow

\section{Result and Discussion}

\subsection{Description of Student Metacognition Awareness}

Identification of students' metacognition awareness carried out with the help of MAI questionnaire instruments produced data as in Table 2. Data in Table 2. shows that more than half of students who are taking the Animal Behavior Course are in a very good level of metacognition awareness (54\%). According to Green (2002) a very good level of metacognition awareness indicates that someone has been able to use metacognition skills regularly to regulate their own thinking and learning processes. They are also aware of the many kinds of thinking possibilities, being able to use them smoothly and reflecting on their thought processes 


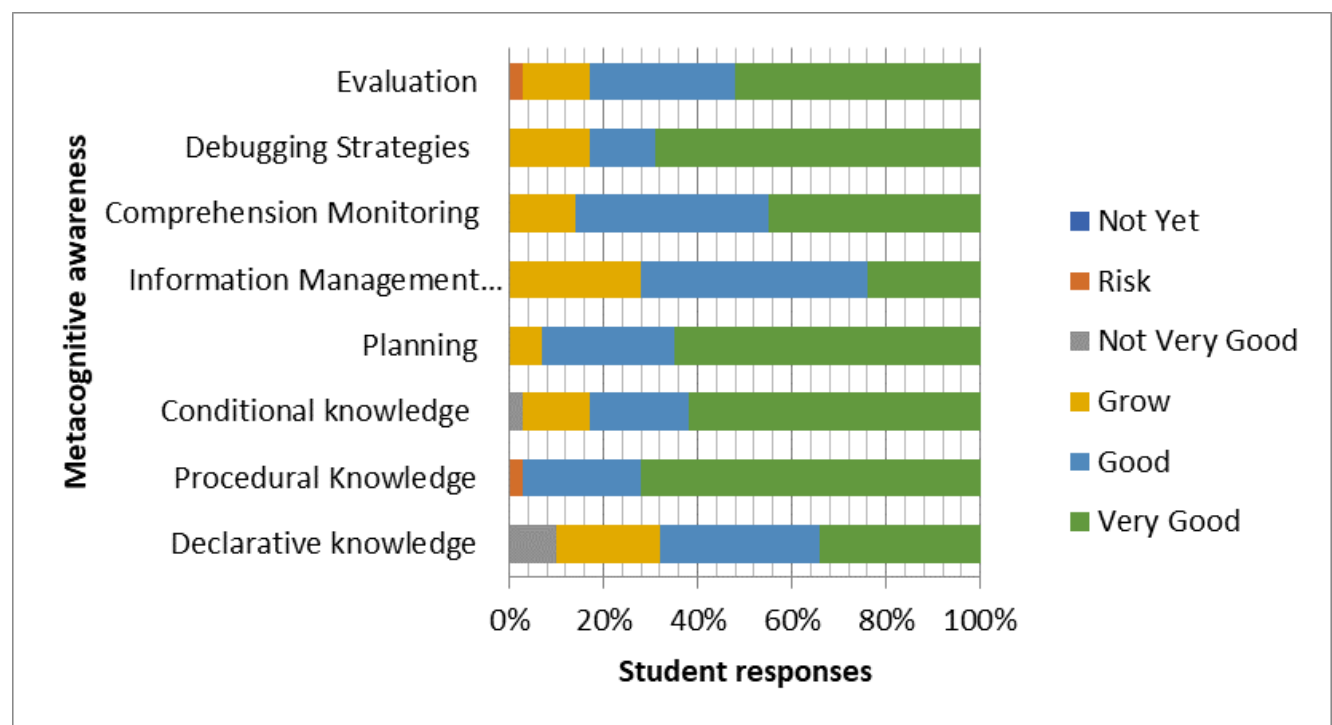

Fig. 2. Analysis of student's responses within each aspect of metacognitive awareness questionnaire

Nearly a quarter (29\%), students are at a conscious level of their own thinking and can distinguish the stages of self-elaboration input and the output of their own thoughts. This level by Green (2002) is categorized in the level of "good" metacognition awareness. While the rest, awareness of metacognition of students is at risk (1\%); not quite able (2\%); and developing $(14 \%)$. Some factors that are suspected to strongly influence the level of metacognition awareness of a student based on the results of research Ulfah et al (2014) are experience, ability to solve problems and the intensity of social interaction.

Metacognition awareness cannot naturally develop in students without being facilitated with appropriate learning strategies [15]. Students who have metacognition awareness levels are at risk, not yet able to, and are still developing can be improved by providing appropriate learning strategies. Conner (2007) states that most students are aware that learning strategies can help direct their metacognitive awareness to a better level. This is shown by the results of Suratno's research [16] which concluded that the combination of jigsaw learning strategies and reciprocal teaching had a significant effect in increasing one's metacognition awareness. One reason that the combined learning strategies are able to increase metacognition awareness is because there is a syntax that requires students to engage in intensive group work interaction and practice an active thought process [17].

The data in Table 2. also presents in detail the level of knowledge and regulation of student cognition. It can be seen that the diversity of students' knowledge level of cognition starts from risk (1\%); not quite able (4\%); developing (12\%); good (27\%); and very good (56\%). Cognitive knowledge includes declarative, procedural and conditional knowledge. The most developed level of knowledge in college students is procedural knowledge (72\%); conditional knowledge (62\%); and declarative knowledge (34\%).

Procedural knowledge is defined by Van de Walle (1990) as an understanding of the order of the rules, the steps used to solve problems. Based on the data in Table 2, the ability of students to understand the steps to solve a problem is very good. The high score is closely related to the habits of students in conducting practical activities. Following sequential steps when practicum, leads to the predicted results or proof. If you do the opposite, the results of the 
practicum will be far from what is desired. Further analysis showed that the average student participating in a lecture on animal behavior was in the third year. It can be assumed that students often do practical activities so that this affects their procedural knowledge.

Furthermore, aspects of student cognitive regulation based on the data in Table 2 in sequence are risky $(1 \%)$; not quite able $(0 \%)$; developing $(16 \%)$; good $(32 \%)$; and very good $(51 \%)$. Cognitive settings include some expertise in planning, information management strategies, comprehensive monitoring, tracking and evaluation strategies. All of these abilities have developed very well for students, only each has a different level. In order the level of development of each of these capabilities are: search strategy (69\%); planning (65\%); evaluation (52\%); comprehensive monitoring (45\%); and information management strategies $(24 \%)$.

The ability in search strategies (debugging strategies) includes knowledge of solutions that must be found and done when finding misunderstanding. The form of the intended solution such as asking the expert when finding difficulties, changing learning strategies when it does not work, reassessing the understanding that is already owned, and re-reading the part that is not understood. Indirectly, this ability has been honed in students' learning experiences. The learning strategy applied by lecturers in lectures is suspected to have a big influence on the development of the ability of the search strategy. Some lecture methods applied by lecturers, such as: assignment to make papers either independently or in groups, classically or groupdiscussion presentations, make observational reports, will indirectly hone the student search strategy.

Whereas the lowest ability in the aspect of regulating cognition is information management strategies. This ability is a strategy chosen by someone in obtaining and interpreting information. Forms of strategy that can be used such as (1) slowing down reading when finding important information, (2) focusing attention, (3) interpreting new information, (4) making examples so that information is more meaningful, (5) making pictures or diagrams when learning, (6) using one's own language style in interpreting information, (7) organizing reading when learning, (8) making steps of learning, and (9) focusing on the overall meaning rather than a part. Some of the problems that can be explored through interviews include students being less able to associate new information with prior knowledge. This is allegedly due to the disruption of the function of the recall in memory and the lack of sensitivity to current environmental issues.

\subsection{The Relationship of Metacognition Awareness with Cognitive Learning Outcomes}

A review of this topic was carried out with the help of the SPSS 16.0 application to ensure the accuracy of the conclusions. Therefore, only using one independent variable, then in determining the strength of the influence of Metacognition Awareness (MA) on Cognitive Learning Outcomes (CLO) using a simple linear regression method. The use of this method has an initial assumption that the data must be normally distributed. To ascertain the type of data distribution used in this study the Kolmogorov-Smirnov method was used. The results of calculations using these methods are presented in Table 3. 
Table 3. Results of calculations using the Kolmogorov-Smirnov method

\begin{tabular}{llr}
\hline & & $\begin{array}{c}\text { Unstandardized } \\
\text { Residual }\end{array}$ \\
\hline $\mathrm{N}$ & Mean & 32 \\
Normal Parameters & & .0000000 \\
& Std. Deviation & 4.05181642 \\
Most Extreme Differences & Absolute & .113 \\
& Positive & .113 \\
Kolmogorov-Smirnov Z & Negative & -.094 \\
Asymp. Sig. (2-tailed) & & .638 \\
\hline
\end{tabular}

The data in Table 3. shows that the significance value obtained at 0.810 is greater than 0.05 , which means that the residual value is normally distributed. Based on these results, the data in this study have fulfilled the initial assumptions so that the process can proceed using the simple linear regression method. The calculation results are presented in Table 4.

Table 4. Calculation of simple Linear Regression

\begin{tabular}{|c|c|c|c|c|c|c|}
\hline & \multirow[b]{2}{*}{ Model } & \multicolumn{2}{|c|}{ Unstandardized Coefficients } & \multirow{2}{*}{$\begin{array}{c}\begin{array}{c}\text { Standardized } \\
\text { Coefficients }\end{array} \\
\text { Beta }\end{array}$} & \multirow[b]{2}{*}{$\mathrm{t}$} & \multirow[b]{2}{*}{ Sig. } \\
\hline & & $\mathrm{B}$ & Std. Error & & & \\
\hline \multirow[t]{2}{*}{1} & (Constant) & 74.716 & 7.289 & & 10.251 & .000 \\
\hline & $\mathrm{KM}$ & .011 & .082 & .024 & .130 & .898 \\
\hline
\end{tabular}

Table 4 shows that the significance value is $0.898>0.05$, it can be concluded that the MA variable has no effect on the CLO variable. So it was decided that the MA variable had no significant effect on the CLO variable. Judging from the level of correlation between MA and CLO students also found no relationship $(\mathrm{r}=0.898)$.

Table 5. Relationship between MA and CLO

\begin{tabular}{llrr}
\hline & & MA & \multicolumn{1}{c}{ CLO } \\
\hline MA & Pearson Correlation & 1 & .024 \\
& Sig. (2-tailed) & & .898 \\
& N & 32 & 32 \\
CLO & Pearson Correlation & .024 & 1 \\
& Sig. (2-tailed) & .898 & \\
& N & 32 & 32 \\
\hline
\end{tabular}

Based on the results of statistical calculations on the three tables above (Tables 3, 4 and $5)$ it is known that Metacognition Awareness (MA) has no significant effect $(r=0.898)$ on the Cognitive Learning Outcomes (CLO) of students in the Animal Behavior Course. The results of the study also support the Danial research report (2010) which concluded that MA had no 
effect on mastering the basic chemistry concepts of students, but simultaneously with metacognition skills had a significant influence. Some studies also did not find a relationship or have a weak relationship between MA and CLO (Centinkaya, 2002; Corliss, 2005; Coutinho, 2007; Suratno, 2009 and Corebima, 2009). However, Ulfah (2014) in her study reported that MA had a strong relationship (38.2\%) with CLO Organic Chemistry. More specifically, Ulfah found that CLO was not fully influenced by MA because there were students with high CLO scores but low MA and vice versa.

Cetinkaya \& Erktin, (2002) reported that MA had a low relationship $(r=0.16)$ with scientific knowledge [18]. Whereas Corliss (2005) even found that MA scores were not related $(\mathrm{r}=0.14)$ to the filling time (both at the beginning and end of learning) and decreased by $49.66 \%$ [19]. Coutinho (2007) also reported that MA had a weak relationship with the academic ability of students $(r=0.21)$ [11]. Furthermore, Suratno (2009) reported that there was no difference in the level of metacognition awareness among students with high academic abilities and students with low academic abilities even though the two groups of students had different responses in learning. Corebima (2009) concluded that the MAI questionnaire was not able to record properly, because of 40 classes (elementary, junior high, high school and PT) levels showed that $30-85 \%$ of participants experienced a decrease in scores from preetest to posttest [20],[21]. Bahri (2010) reported a decrease in metacognition awareness from pre-test to post-test using the MAI questionnaire by $25 \%$ of 44 students [22].

No significant relationship was found between MA and CLO because it was allegedly strong because the level of knowledge contained in the CLO test instrument was C1 and C2. While knowledge of metacognition tends to lead to setting high order thinking skills. So there is no / little harmony found in the variables $\mathrm{X}$ and $\mathrm{Y}$. The statement is in line with the results of Danial's research (2010) that MA does not have a significant relationship with the mastery of students' basic chemical concepts [23]. Mastery of concepts tends to be normative and theoretical, meaning that students are asked to remember and understand theories, laws and principles in chemistry. Students have not been asked to apply, analyze, assess and create. But Danial (2010) found that metacognition skills had a significant effect on student CLO [24]. Metacognition skills are closely related to how a person (1) plans, (2) monitors and (3) evaluates. These three capabilities will develop optimally and synergy if based on a good understanding of the concepts, theories and principles in chemistry. Based on this, it can be seen that the component of metacognition skills is complex abilities that lead to higher order thinking skills. So the common thread is that if a student's metacognitive skills are good, the student's learning outcomes are also good.

\section{Conclusion}

The level of metacognition awareness of students in animal behavior courses is at various levels. Starting from very good (54\%), good (29\%), growing (14\%), not very able (2\%) and risky (1\%). Meanwhile, no significant relationship was found between metacognition awareness and student learning outcomes. This condition is allegedly strong because the test instruments used to measure learning outcomes are at the level of knowing and understanding. While metacognition is very closely related to higher order thinking skills. It is necessary to develop in the test instrument learning outcomes towards more authentic and demanding higher-order thinking. An appropriate learning strategy is needed in developing students' metacognition awareness. However, metacognition awareness is very closely related to the regulation of cognition. 


\section{References}

[1] Rickey, D., \& Stacy, A. M. The role of metacognition in learning chemistry. Journal of Chemical Education, 2000. 77(7), 915-920.

[2] Tomlinson, C. A., Brighton, C., Hertberg, H., Callahan, C. M., Moon, T. R., Brimijoin, K., Conover, L. A., \& Reynolds, T., Differentiating instruction in response to student readiness, interest, and learning profile in academically diverse classrooms: A review of literature. Journal for the Education of the Gifted, 2003. 27(2-3), 119-145. https://doi.org/10.1177/016235320302700203

[3] Susantini, E., Memperbaiki kualitas proses belajar genetika melalui strategi metakognitif dalam pembelajaran kooperatif pada siswa SMU. Disertasi, 2004.

[4] Veenman, M. V. J., Wilhelm, P., \& Beishuizen, J. J., The relation between intellectual and metacognitive skills from a developmental perspective. Learning and Instruction, 2004. 14 (1), 89109. https://doi.org/10.1016/j.learninstruc.2003.10.004

[5] Azevedo, R., Theoretical, conceptual, methodological, and instructional issues in research on metacognition and self-regulated learning: A discussion. Metacognition and Learning, 2009. 4(1), 87-95. https://doi.org/10.1007/s11409-009-9035-7

[6] Baker, W., \& Czarnocha, B., Written meta-cognition and procedural knowledge. Educational Studies In Mathematics, 2002. 32, 1-36.

[7] Anderson, L. W., \& Krathwohl, D. R., A Taxonomy for Learning, Teaching and Assessing. 2001.

[8] Ulfah, M., Erlina, \& Kurniawan, R. A., Analisis Kesadaran Metakognisi dan Hubungannya dengan Hasil Belajar Mahasiswa pada Mata Kuliah Kimia Organik Program Studi Pendidikan Kimia UM Pontianak. 2013.

[9] Pintrich, P. R., The Role of Metacognitive Knowledge. 2011.

[10 ]Nuryana, E., \& Sugiarto, B., Hubungan Keterampilan Metakognisi dengan Hasil Belajar Siswa Pada Materi Reaksi Reduksi Oksidasi (Redoks) Kelas X-1 SMA Negeri 3 Sidoarjo. Journal of Chemical Education, 2012. 1(1), 83-91. https://doi.org/10.1017/CBO9781107415324.004

[11] Coutinho, S. A., The relationship between goals, metacognition, and academic success. Educate , 2007. 7(1), 39-47.

[12] Ainun Fauziah, H., Putri Setyowati, A., Dewantari, R., Dwi Wulandari, A., \& Adi Prayitno, B., Profil Kesadaran Metakognisi Siswa di salah satu SMA Swasta di Sragen. BIOSFER: Jurnal Biologi Dan Pendidikan Biologi, 2019. 3(1). https://doi.org/10.23969/biosfer.v3i2.975

[13] Nawawi, H., Metode Penelitian Bidang Sosial. Gadjah Mada University Press. 2008.

[14] Schraw, G., \& Dennison, R. S., Assessing metacognitive awareness. In Contemporary Educational Psychology. 1994. (Vol. 19, Issue 4, pp. 460-475). https://doi.org/10.1006/ceps.1994.1033

[15] Li, C., \& Nietfeld, J. L., College students' metacognitive awareness of difficulties in learning the class content does not automatically lead to adjustment of study strategies. Australian Journal of Educational and Developmental Psychology, 2007. 7(678), 31-46.

[16] Suratno, Kemampuan Metakognisi dengan Metacognitive Awareness Inventory (MAI) pada Pembelajaran Biologi SMA dengan Strategi Jigsaw , Reciprocal Teaching (RT), dan Gabungan Jigsaw - RT. Jurnal Pendidikan Dan Pembelajaran, 2011. 18(1), 11-18.

[17] Palincsar, A. S., \& Herrenkohl, L. R., Designing collaborative learning contexts. Theory into Practice, 2002.41(1), 26-32. https://doi.org/10.1207/s15430421tip4101_5

[18] Cetinkaya, P., \& Erktin, E., Assessment of Metacognition and its Relationship with 
Reading Comprehension, Achievement, and Aptitude. 2002.

[19] Corliss, S. B., The effects of reflective prompts and collaborative learning in hypermedia problem-based learning environments on problem solving and metacognitive skills. The University of Texas at Austin, 2005. 1-138.

[20] Amin, A. M., \& Corebima, A. D., Analisis Persepsi Dosen Terhadap Strategi Pembelajaran Reading Questiong And Answering (RQA) Dan Argument Driven Inquiry (ADI) Pada Program Studi Pendidikan Biologi Di Kota Makassar. Prosiding Seminar Nasional II, 2016. March, 333-347. https://www.google.com/url?sa=t\&rct=j\&q=\&esrc=s\&source=web\&cd=33\&cad=rja\&u act=8\&ved=0ahUKEwiGn6mWxNDWAhXMq48KHbrbAVsQFgi7AjAg\&url=http\%3 A\%2F\%2Fresearch-report.umm.ac.id\%2Findex.php\%2Fresearchreport\%2Farticle \%2Fdownload\%2F631\%2F841\&usg=AOvVaw3CfSinqbiQAHB

[21] Ardila, C., Corebima, A. D., \& Zubaidah, S. Hubungan Keterampilan Metakognitif Terhadap Hasil Belajar Biologi dan Retensi Siswa Kelas X Dengan Penerapan Strategi Pemberdayaan Berpikir Melalui Pertanyaan (PBMP) Di SMAN 9 Malang. Jurnal Pendidikan: Teori, Penelitian, Dan Pengembangan, 2013. 1-9. http://jurnalonline.um.ac.id/data/artikel/artikelEE88BC4B01504CB71615F1D280FAF7AE.pdf

[22] Bahri, A., Pengaruh Strategi Pembelajaran Reading Questioning and Answering (RQA) pada Perkuliahan Fisiologi Hewan terhadap Kesadaran Metakognitif, Keterampilan Metakognitif dan Hasil Belajar Kognitif Mhs. Jurusan Biologi FMIPA Universitas Negeri Makassar. UM. 2010.

[23] Danial, M. Menumbuhkembangkan Kesadaran Dan Keterampilan Metakognisi Mahasiswa Jurusan Biologi Melalui Penerapan Strategi Pbl Dan Kooperatif Gi. BIOEDUKASI (Jurnal Pendidikan Biologi), 2010a. 1(2). https://doi.org/10.24127/bioedukasi.v1i2.188

[24] Danial, M. Pengaruh Strategi PBL Terhadap Keterampilan Metakognisi dan Respon Mahasiswa The Effects of PBL Strategy to Students Metacognition Skill and Respon. Chemica, 2010b. 11, 1-10. 